\title{
Policy Implementation of Management of Rehabilitation and Reconstruction Grants Fund (Study in Pidie Jaya District and Pidie District in Aceh Province)
}

\author{
Ria Suwartiningsih ${ }^{1,}$ Vishnu Juwono ${ }^{2 *}$ \\ ${ }^{1}$ Faculty of Administrative Science, Universitas Indonesia \\ ${ }^{2}$ Faculty of Administrative Science, Universitas Indonesia \\ *Corresponding author. Email: vjuwono@ui.ac.id
}

\begin{abstract}
The post-disaster recovery process is the responsibility of all parties, government, society, and private sector. The Rehabilitation and Reconstruction Grant Fund is a manifestation of the responsibility of the central government in accelerating the recovery from the effects of the disaster. Management of rehabilitation and reconstruction grants in the regions is carried out by the Regional Disaster Management Agency. This study evaluates not only the content but also the context of the policy around the implementation of the management of grant and rehabilitation funds. Pidie and Pidie Regencies have implemented Perka policy No. 4 of 2015, although not fully. Policy implementers influence implementation of grant and rehabilitation management in Pidie and Pidie Jaya Districts at the policy content level, whereas the political environment influences policy implementation in Pidie District and Pidie Jaya Regency at the contextual level.
\end{abstract}

Keywords: Implementation, Policies, Rehabilitation and Reconstruction

\section{INTRODUCTION}

The post-disaster impact recovery process is the responsibility of all parties, be they the central government, local government, community, or private sector. In 2017, the Ministry of Finance had set a budget for rehabilitation and reconstruction grant assistance of Rp. 1,701,140,640,000.

Pidie District and Pidie Jaya Regency were two of the districts in Aceh Province affected by the 6.5magnitude earthquake of December 2016. In accelerating the recovery from the disaster, Kabupaten Pidie was allocated Rp. 66,734,530,000, whereas Pidie Jaya Regency received an allocation of Rp. 343,511,900.

However, there were a number of differences between Pidie District and Pidie Jaya District. In the 1 year monitoring and evaluation report, the Pidie Jaya District budget was only able to absorb $25.98 \%$ for financial realization and $61 \%$ for its physical realization. Meanwhile, Pidie District only consumed
$2.12 \%$ for financial realization and $13 \%$ for physical realization.

In this study, we will look at the analysis of the implementation of the grant and rehabilitation fund management policies in terms of processes, benefits, and impacts, whereas in examining the factors that influence the implementation of the policy researchers, we will look at the content and environmental (context) policies.

\section{RESEARCH METHOD}

In examining the implementation of rehabilitation and reconstruction grant management policies, researchers used a post-positivist approach with qualitative data collection methods. The postpositivist approach is used to achieve a comprehensive understanding of the issues through in-depth interviews and participatory observation, helping us understand the meaning of phenomena and the symbolic meaning behind reality. 


\section{RESEARCH RESULTS AND ANALYSIS}

\subsection{Process}

\subsubsection{Planning and budgeting}

After the rehabilitation and reconstruction grants are transferred to the regional general cash account, according to Perka Number 4 of 2015, both the rehabilitation and reconstruction of grant management activities are carried out by the Regional Disaster Management Agency (BPBD).

The planning of activities prepared by the BPBD will refer to the action plan already prepared. The action plan is prepared by the local government and accompanied by BNPB. The document itemizes the damage and losses caused by the disaster in various sectors.

\subsubsection{Implementation}

From field observations and the results of interviews, researchers in the field made several findings related to the problems of managing rehabilitation and reconstruction grants in Pidie Jaya Regency:

1. A change in plan (design) on rehabilitation work items for the Public Works Office office building in Pidie Jaya Regency;

2. Obstacles to the provision of fabrication of concrete piles and girders in the construction of the Lhok Puuk Bridge;

3. Verification and re-registration of the prospective recipient of home improvement stimulant funds.

Similarly to Pidie Jaya District, Pidie Regency proposed an extension of the work time. The following can be explained by the obstacles to managing rehabilitation and reconstruction grants in Pidie District:

1. Pidie District has a new Regional Head. Furthermore, the Working Group has changed procurement processes for goods and services that were implemented by the previous District Head.

2. The APBD mechanism that exists in the management of grant funds turns out to be a separate obstacle.

3. It was also in Pidie District that the community rejected the data from the initial verification conducted after the earthquake.

The implementation of the management of the rehabilitation and reconstruction grants in both districts faces many obstacles. The technical constraints are within the infrastructure work activities, whereas non-technical constraints in the form of social problems or symptoms of social conflict occur in the district community. These constraints emerge because of home stimulant assistance funds that are given directly to the community.

\subsubsection{Report and supervision}

BNPB itself has created an online reporting application, e-reporting. Where Pidie Jaya and Pidie Districts can report activities regularly and periodically through the online system, BNPB can always monitor that progress.

\subsection{Benefits}

The Pidie District and Pidie Jaya District communities acknowledge that these funds are very beneficial for them, especially home improvement stimulant grants. Stimulant housing assistance is given directly to the community. With this pattern, people feel directly involved in the construction of their homes, because they can design and participate in building them according to their desires. The value of assistance is determined by damage criteria.

\subsection{Impact}

In general, the real impact that Pidie Jaya and Pidie District felt from the allocation of this grant was that it restored people's lives to a pre-disaster state. No less important is the positive impact of rehabilitation and reconstruction grants, namely, increasing self-help and community participation.

Several factors influence the implementation of the rehabilitation and reconstruction of grant management policies.

\subsubsection{Content of Policy}

\subsubsection{Policy-Influenced Interests}

(1) Ministry of Finance

The Ministry of Finance uses funds from the grant. After the proposed allocation of grants and prospective recipients of grant assistance from BNPB, the Director-General of Balance at the PPA will prepare the State General Treasurer RDP (Expenditure Fund Plan), together with the Director of Regional Financing and Capacity.

\section{(2) BNPB}

The National Disaster Management Agency is a non-ministerial government institution acting as an 
Executing Agency responsible for grant programs in the context of assistance in funding rehabilitation and reconstruction. With this provision, it is clear that BNPB is accountable for the entire grant implementation process, from the process of channeling funds to the regions to supervising their implementation, up to collecting accountability reports from the recipient regions to be submitted to the Ministry of Finance.

(3) District Government/Regional Disaster Management Agency (BPBD)

The Regional Disaster Management Agency has been given the authority to manage rehabilitation and reconstruction grants.

From some of the descriptions above, it can be seen that BNPB is the most influential stakeholder in the policy content level of Perka No. 4 of 2015.

\subsubsection{Degree of Change to be Achieved}

As to the degree of change desired in the management of rehabilitation and reconstruction grants in Pidie District, even though the extension is a one-time extension, activities can be completed properly during the extension, so that at the end of December 2018, Pidie District had completed 99.48\% of jobs.

\subsubsection{Program Implementation}

\section{BNPB}

BNPB is the institution in charge of the rehabilitation and reconstruction program grant program from the central government to local governments. On the basis of its authority, BNPB must ensure that the program runs in accordance with its objectives and can be implemented properly.

\section{BPBD}

The successful implementation of the grant and rehabilitation management policy is based on Perka Number 4 Year 2015. Therefore, it will depend on the proper implementation of these policies by BPBD of Pidie Jaya Regency and Pidie Regency.

\section{BKD}

The Regional Finance Agency is a related service agency in the area that supports the implementation of this policy. In terms of determining the allocation of grant funds, BNPB held a socialization program for the previous BKD. The BNPB would explain that this grant has a unique feature whereby these grants can be allocated at any time to the regions without being limited to the fiscal year. With the socialization, the BKD is better prepared to adjust the use of this grant to the APBD mechanism..

\section{Community groups (Pokmas)}

Community groups were created to fulfill one of the requirements for providing home improvement stimulant assistance. Each community group will appoint a community leader who coordinates the disbursement of aid funds, constructs houses, and reports on the use of grants for home improvement.

\section{Facilitator}

The facilitator plays a role in assisting the community at each stage of the development of his house. The facilitator also approaches the community in solving current social problems, such as re-verifying the numbers and criteria of the house that the community perceives as inappropriate.

\subsubsection{Resource}

In managing grant rehabilitation and reconstruction grants, Pidie Jaya and Pidie Districts have limited resources. Among them are human resources, namely, the limited number of employees in the two districts.

Furthermore, the number of BPBD staff is not sufficient; the budget provided by the Regional Government to the BPBD is also tiny. The budget for the rehabilitation and reconstruction program in Pidie Jaya Regency in 2018 is only Rp. 2,705,056,640 or a mere $0.23 \%$ of the Pidie Jaya Regency budget of Rp. 11,735,173,494. Likewise, the budget for Pidie Regency BPBD is only Rp. $953,030,000$ or $11 \%$ of the total APBD budget of Rp. 8,770,000,000.

\subsubsection{Context of Implementation}

3.3.2.1. Power, interest, and strategy of the actors involved in the implementation of management of the rehabilitation and reconstruction grant:

\section{BNPB}

$\mathrm{BNPB}$, as the executing agency, is responsible for implementing the grant and reconstruction program. The responsibility started from the beginning of the implementation, whereby BNPB verifies all proposed disaster management funds offered by the region.

\section{Local government}

Local government should be able to provide full support for the management of rehabilitation and reconstruction grants, accelerating both budget use agreements and other policies. 
As with Pidie Regency, the replacement of the Regional Head resulted in a delay in the work auction activity.

\subsubsection{Characteristics of institutions and rulers}

Pidie Jaya BPBD and Pidie Jaya BPBD have been included in the type-A criteria. With this type, the two regencies have fulfilled the requirements for managing the funds.

\subsubsection{Level of compliance and implementing response}

Pidie Regency has complied quite effectively with grant management activities. The extension is only granted once, for 6 months, and Pidie Regency is able to complete $99.48 \%$ of operations.

From the May 2019 report, it can be seen that the financial realization of Pidie Jaya Regency was $99.22 \%$ and physical construction realization was $93.05 \%$

\section{CONCLUSION}

Implementation of the management of grant rehabilitation and reconstruction in Pidie and Pidie Jaya Districts went well, although its execution was not optimal. Despite the extension of work time, all the activity items in the activity plan were completed. In the process of implementing the second district grant management, there were numerous challenges. The social problems emerge in home improvement stimulant assistance and in the unavailability of supporting material resources for other infrastructure development. While in the planning and reporting stage, not too many obstacles hampered the activity process. The communities of the two districts have greatly benefited from the allocation of grant funds, whereby lives can be saved from disaster. The expected impact of the recovery of community life is that the community and local government are independent when disasters occur, which allows them to allocate the budget for disaster management, so the impact of the disaster can be immediately handled without a long wait for the central government.

The problems that occurred in the two districts resulted in the two districts being unable to complete the grant management activities on time. In the context of the policy, namely, the environment, it can be seen that the political climate has quite an influence on implementing policies. For instance, in Pidie District, there was a sudden change in regional heads. As a result, the head of BPBD is in the middle of his term. This results in the work being done promptly.

By way of suggestion, a PDRP (Pre-Disaster Recovery Plan) is urgently needed. This is a kind of recovery plan that should be prepared by each district, which is prone to a natural disaster. When the natural disaster arises, the local government will not need to prepare an action plan and a damage and loss assessment document.

\section{REFERENCES}

[1] Godin, R.E., Rein, M. and Moran, M. 2006. The Public and its Policies. New York: Oxford University Press

[2] Grindle, M. 2017. Politics and Policy Implementation in the Third World.New Jersey: Princeton Legacy Library

[3] Grindle, M.S. 1980. Politics and Policy Implementation in The Third World. New Jersey: Princeton University Press

[4] Kroehnert, G. 2005. Post Disaster Recovery Guidelines.

[5] Parsons, W. 2017. Public Policy: Introduction to Theory \& Practice of Policy Analysis. Jakarta: Kencana

[6] Pinkowski, J. 2008. Tolley's Handbook of Disaster and Emergency Management. Elsevier. Amsterdam

[7] Regulation of the Head of the National Disaster Management Agency Number 4 of 2015, Grants from the Central Government to Regional Governments in the framework of Post-Disaster Rehabilitation and Reconstruction Funding Assistance.

[8] Ripley, R.B. and Grace, A.F. 1986. Policy Implementation and Bureaucracy. United Kingdom

[9] Thoha, M. 2012. Dimensions of Prima State Administration. Jakarta. Raja Grafindo Persada

[10] Van, M., Donald, S. and Carl, E.V.H. 1975. The Policy Implementation Process: A Conceptual Framework. Administration and Society. 6.

[11] Wahab, S.A. 2010. Introduction to Analysis of Implementation of State Policy. Jakarta. Rineka Cipta.

[12] Winarno, Budi. 2007. Theory and Process of Public Policy. Yogyakarta. Media Pressindo 